\title{
Beyond the Legalistic and Mechanical Approaches to Conflict Management in Nigeria
}

\author{
Ko, Viashima David \\ Department of Philosophy/University of Ibadan, Nigeria
}

\begin{abstract}
Multiethnic and religious crises are exposing Nigeria to its greatest existential problem of all time. Calls for separation and self-determination are vociferous among Nigeria's ethnic, religious, and socio-cultural groups. While Nigeria's government and well-meaning organizations are engaging the problem, ongoing conversations on the matter focus on the potentials of legalistic and mechanical approaches to conflict management. Ethnic and religious conflicts in Nigeria are resisting these formulations and sustaining the path of destruction, pulverizing economic, social, human, and material resources.

This paper supplements existing perspectives on conflict management in Nigeria with an ontological approach. It defends the need to explore the ego, the self, the $I$ in managing conflicts in Nigeria. With categories and frameworks mined from existentialists philosophers, the paper advocates the development of systematic processes of reorientation based on the existentialist values of intersubjectivity, tolerance, dialogue, understanding, care, and solidarity as a tool against the religious and ethnic crisis in the country.
\end{abstract}

Keywords: Existentialism, ethnicity, ethnoreligious conflict, intersubjectivity, care.

\section{INTRODUCTION}

$\mathrm{N}^{\mathrm{i}}$ igeria is laced with highly insidious and obstinate conflicts. A critical focus on these lethal schisms suggests religious differences and ethnic commitments as leading causal factors. In the north, south, east, and western regions of the country, ethnoreligious conflicts obscure peace, challenge development prospects, and pulverize human and material resources (Onah, Diara \& Uroko, 2019: 61).

Several dynamics shape ethnoreligious conflicts and peace prospects among Nigerian ethnicities and religious groups. First, ethnic and religious particularities are the most socially and politically vibrant forms of identity in Nigeria. Second, there seems to be a general propensity among Nigerians to distribute privileges and develop relationships based on religious and ethnic compatibilities. Third, Nigerian ethnicities and religious groups are trapped in severe asymmetrical power struggles, such that these groups elect their interests in ways that undermine the interests of others, and apply these interests to legislate religious and social correctness. While these dynamics are sometimes less disruptive, they can act as springboards for material, social and human destruction when applied to perpetually discriminate, extract privileges, usurp, and dominate the interest of others in plural or religiously diverse society (Oyeshile, 2005:10).

This paper argues that radical ethnocentric commitments by ethnic and religious groups aggravate ethnoreligious conflicts and subvert peace efforts in Nigeria. The paper understands ethnocentric commitments as the tendency by ethnicities and religious groups to radically elect their interests above the interests of other stakeholders, and to apply these interests to perpetually extract undue privileges, discriminate, usurp power structures, undermine and dominate competing parties. Ethnocentric commitments utilise the interests of the dominant groups as validation models and apply these models to legislate the interests of others in ways unfavourable to them. Hence, the paper argues that an ambitious effort for peace among Nigerian ethnicities and religious groups consists of developing and entrenching intersubjective structures that facilitate genuine discourse, cooperation, understanding, tolerance, acceptance, and mutual exchange of values.

\section{CONCEPTUALISING ETHNICITY AND RELIGION}

\section{Ethnicity}

There are many interpretations of ethnicity. Weber (1968) uses ethnicity in reference to human collectives with subjective beliefs in their ancestery because of particularities such as customs, physical character or both, or because of their common memories of colonisation or immigration (Weber, 1968: 389). Schermeorn (1970: 12) defines it as a social collective with real or putative origin, memories, shared history and a cultural inclination towards certain symbolic elements relevant to their identity (Schermerhorn, 1970: 12). He uses "symbolic elements" to refer to tribal affiliation, kingship patterns, physical contiguity, language or dialect, phenotypical features and nationality.

This paper construes an ethnic group as a population that:

(a) Is largely biologically self-preserving

(b) Is identified with basic cultural values and ancestry

(c) sees itself, and is understood by others, as a distinguished category from other categories of a similar order.

(d) shares a unique field of communication and interaction.

A group should evince these characteristics in significant ways to qualify as an ethnic group. 


\section{Religion}

Adeniyi (1993) construes religion as a body with shared laws, rites and truth which subordinate the human person to a supernatural being. It involves spiritual principles, beliefs, and rules from a transcendent being which are expected to be obeyed by believers. Religion also refers to a structure or range of systems with shared doctrines, myths, rituals and inclinations among other similar elements (Ayinla, 2003). Durkheim (1965) believes that religion involves certain practices, ways of thinking, and beliefs unique to such institutions.

Smith (1970) argues that religion has subsisted over time as an important cultural, economic and political element. Huntington (1993) narrates how religion and its cultural structures drive modern culture and global politics. In politics, for example, religious structures are often invoked to undermine or bolster political legitimacy (Fox and Sandler 2003). Hence, religion acts as one of the main instruments that legitimise or illegitimate political regimes (Nasr, 1998; Haynes, 1994.).

Fox (1997) sees religion as an important domain of ethnicity and an influential form of identity which can inspire acrimony and discord among groups. According to him, "religion is salient if it is a defining trait that sets a group apart," and can shape all forms of a group's sociopolitical activities (Fox \& Sandier, 2003: 562). Hence, we can explore religion to discriminate against other religious and ethnic identities. Fox (1999) argues that religious institutions may rebel when their values are exposed to severe and sustained discrimination or threat. It is more challenging when religious groups explore force to assert or defend their principles or values (Fox \& Sander, 2003:566).

\section{CASES OF ETHNORELIGIOUS CONFLICTS IN NIGERIA}

Ethno-religious conflicts involve groups whose social and cultural lives are influenced by religion which plays representative and legitimising roles with the potential to mobilise interests towards a goal. In Nigeria, ethno-religious conflicts have risen since the 1980s. Consider the 1980 Maitastine riot in Kano and Borno States that caused the deaths of at least four thousand people. According to Njoku (2020):

The Maitatsine riots were a series of violent uprisings instigated by Islamist militants in northern Nigeria between 1980 and 1985 and represented northern Nigeria's first major wave of religiously inspired violence. The riots prompted immense ethno-religious discord between Muslims and Christians in years to come (Njoku, 2020: 13).

Other cases include the Kafanchan crisis of 1987 which was a response to a crusade by Christian members of the College of Education, Kafanchan. The crisis spread to Funtua, Zaria and the Kaduna metropolis. At least twenty-five (25) people were killed. In 2001, ethno-religious conflicts between the Hausa and the Ibo displaced over Five Hundred Thousand people (Isiramen, 2010). These attacks happened in Onitsha, Anambra State. Apart from these examples, Boko Haram's violent insurgency in Nigeria, which began in 2009, has led to thousands of deaths. In 2020 alone, the group killed at least One Thousand Six Hundred and Six people ( SB Morgen, 2020).

Although the Nigerian media, including foreign sources, translate Boko Haram as "Western education is forbidden" (Vanguard, 2018), an official statement from Boko Haram has addressed the group as Jama'atu Ahlissunnah Lidda'awati Wal Jihad, meaning a "People Committed to the Propagation of the Prophet's Teachings and Jihad" (Onouha, F.C. 2012). As Onouha (2012) notes, although Boko Haram has altered its identity severally over the years, the organisation aims to overthrow the Nigerian State and implement radical sharia laws across the country.

A plethora of commentaries suggest Boko Haram, a religious configuration, has ethnic colourations, and that it is used to facilitate an ethnic agenda. Some contributions to the foundational motivations of Boko Haram suggest the Hausa/Fulani group use Boko Haram to gain political and economic benefits at the detriment of other ethnic nationalities.

Conspiracy theories accusing Northern politicians of sponsoring insurgency in the north to make the country ungovernable for political actors from other regions have driven political calculations during election periods. In 2015, for example, there were allegations that the Northern Muslims were using Boko Haram to frustrate and destabilise the national government led by a Southern Christian. Kimenyi, et al. (2014) explain better:

This theory is very popular among commentators and leading politicians from the southern part of the country. President Jonathan is a southerner from the minority Ijaw ethnic group. According to the theory, people from the north, essentially the "core north" (that is, the Hausa/Fulani), believe it is their birthright to govern the country, and because a Christian southerner is in charge, they sponsored Boko Haram as an instrument for destabilising the Jonathan's presidency (Kimenyi, et al. 2014: 33).

A counter-theory suggests Boko Haram is funded and sustained by the southerners to depopulate the northern region and mobilise support for the government of a southern Christian. According to Kimenyi, et al. (2014):

Another conspiracy theory is that Boko Haram is usually sponsored by the Jonathan administration to make Islam look bad or give the impression that the north is out to pull down his administration ... A variant of this theory is that Boko Haram is 
sponsored by the government to weaken, destroy or reduce the population of the north ahead of the 2015 elections...leaders from the north, including the governor of Adamawa, Murtala Nyako, and governor of Sokoto State, Alhaji Aliyu Wammakko, have legitimised this theory by coming out to subscribe to it openly (Kimenyi, et al. 2014: 33).

Obvious incongruities with these theories are not our concern. We are interested in these conspiracies' tendency and ability to brew ethnic attacks and retaliations, interregional stigma, hatred and threats of disintegration. They also underscore the fluidity of ethnic and religious crisis, especially how these domains of discord influence eachother.

Apart from Boko Haram, the ongoing conflict between the Tiv and Fulani people in Nigeria's north region is compelling. Although the conflict is believed to be farmers versus herders' crisis, there are strong claims that the conflict is an attempt by the Fulani to actualise a failed project of territorial usurpation and ethnic cleansing attempted by Usman dan Fodio during the great Jihad against the people of Benue and their valley. Mr Terver Akase, the spokesman to the Benue State Governor, claimed during an interview with the Punch Newspaper in December 2018 that "the agenda to take over Benue State by the Fulani is still there. They have not given up." Similarly, a former commissioner in the State, Honourable Rebecca Apedzam, in an interview published by the Vanguard Newspaper in May 2018, claimed that the crisis is aimed at usurping the Benue valley from its indigenous ethnicities. According to Apedzam (2018):

The truth is that it is all about land, Fulani herdsmen want to sack us from our land. They had said it before that they wanted the Benue Valley which they said was their ancestral land... whenever they attacked, they destroyed all the houses, burnt down others so that nobody could stay there which they would then occupy (Vanguard News online, 2018)

The Fulani have claimed that grazing is a cultural phenomenon, and that grazing through Benue had no specific aims beyond the expression of their traditional obligations towards their culture. Apart from these crises, there are ethno-religious conflicts between the Itsekiris and Ijaw, Igbo versus the Hausa, Yoruba versus the Fulani, among others. Such conflicts have brewed pressure groups and ethnic militias such as the Niger Delta youths and the Egbesu boys in the South-South, the Odua People's Congress (OPC) and Afenifere in the South-West, The Arewa People's Forum and the Northern Elder's Forum in the North, Ohaneze Ndigbo, in the South-East, Christian Association of Nigeria, and Muric, to mention a few. These groups have pursued a wide range of goals including power and resource control, the exercise of religious rights, the entrenchment of religious legal systems, control over territory, oil derivation, privatisation and revenue distribution among others.

\section{CAUSES OF ETHNORELIGIOUS CONFLICTS IN NIGERIA}

Several theories accuse the struggle for economic control and political power of perpetuating ethnoreligious conflicts in Nigeria. Others flag ethnic attachments and historical divisions in religious ideologies as leading causes of ethnoreligious disputes. While these narratives are substantial, we are critical of their disregard for the role of the ego, the I, in brewing conflicts. There are several reasons while ignoring the roles of the I, the ego, has deleterious implications for our quest for religious and ethnic stability in Nigeria. First, the ego, the self, has its projects which are critical to its authenticity and survival. Second, the self's understanding of its projects and the means of achieving them is critical to how it forms its worldviews and builds relations with the outside world. Third, since our world is a connected one, and the self does not exist in insolation, the kind of worldwiews it embraces, and how it implements them, impacts how it connects to competing egos. A self that commits to its interests above the interests of others, for example, is likely to suffer prejudice and hate.

In the Nature of Prejudice, G.W Allport (2005) identifies five features likely to be displayed by a prejudiced person towards another. These include:

One, negative remarks: the subjects speak despairingly about groups they dislike.

Two, avoidance: the prejudiced subjects avoid those who are not part or members of the group.

Three, discrimination: the prejudiced group malign the other significant aspects, including employment, social privileges, places of residence among others.

Four, physical attack: the prejudiced subject becomes violent, and embraces violence to intimidate those outside his group.

Extermination: the prejudiced person takes part in massacres, lynching, extermination programmes among others (Allport, 2005)

The ego, the self, thus, plays very important roles in shaping the nature and character of our existential relationships, including our ethnic and religious relations.

\section{AN EXISTENTIALIST SOLUTION TO ETHNORELIGIOUS CONFLICTS IN NIGERIA}

Efforts to resolve ethno-religious conflicts and establish peace among the various religious and ethnic groups in Nigeria have either failed to achieve lasting solutions or outrightly disappointed expectations. This is because these efforts focus on the legalistic and mechanical approaches to conflict resolution. By legalistic approaches, we mean laws enacted to compel behaviour in certain ways that benefit the interest of certain groups. Mechanical approaches, as used here, are military and paramilitary efforts. While these instruments are vital for order, regardless of the status of the society, they are 
grossly inadequate when building sustainable approaches to peace in plural societies. Apart from escalating descent and perpetuating economic, material, and human waste, mechanical approaches to peace influence a culture of historical revenge, disdain, and hate.

Legalistic efforts, like mechanical approaches, summarily restore order between two dissenting parties without addressing the core issues responsible for the acts. Consider the Anti-grazing bill enacted by the Benue State government to quell attacks and invasion by the Fulani's, for example. While the bill has reduced the level of attacks, it is unclear whether the bill has addressed the main contentions of the conflict, especially the claim by the State Government that there is a historical desire by the Fulani to usurp and convert the Benue valley to their ancestral land. It is also unclear whether the bill has changed the attitude of the minds that seek the usurpation. It is the gap between legalistic and mechanical approaches on the one hand, and the attitudes of the mind that brew these conflicts on the other that makes the existentialists' philosophy of intersubjectivity an important response to ethno-religious conflicts and our quest for peace in Nigerian societies.

Unlike mechanistic and legalistic efforts, the existentialist approach focuses on attitudes of the mind which can provoke, inspire or brew conflicts. The focus on the role of the self, the ego, the I, in conflict generation and resolution is important for some reasons. First, the various actors are egoistical, radically commited to a spurious authenticity. This is similar to the existentialist project of subjectivity in which the poursoi, the cogito, claims a central role and place in the world. Second, religious and ethnic groups exclude others in pursuing their goals and distributing welfare. With this, they undermine the existentialist view of the world as a withworld. Third, conflicts are ontological. They are inevitable outcomes of concrete human relationships. As Unah (2000:237) notes, "conflicts do not occur in a Robinson Crusoe situation. They occur from social relatedness. Insofar as we are human beings living in human society, conflicts cannot but occur" (Unah, 2000:237).

Unah's argument underscores the inevitability of conflicts at the interpersonal level. Moreover, with the growing complexity of plural societies, and their differences in historical, cultural, economic, political and social values, plural societies are prone to antagonism, hate, discrimination, tensions and crisis (Jamieson, 2004). There is, thus, the need for ontological and moral structures that supply the justification for upholding what, following existentialists philosophers, we refer as the "truth of being" among the various stakeholders.

There are several ways in which existentialists understand the notion of the truth of being, but Heidegger's (1963) concept of this idea serves us better. Heidegger argues that the "concept of the 'meaning of being' and the 'truth of being' mean the same." Heidegger presents being as the "possibility of understanding oneself; that is, as linked to the ethical practice of Being-in-the-world." According to Unah (1996) Heidegger uses this notion of being to establish the interdepency and intersubjectivity of being. As Unah explains:

The awareness of the being of others is part of the awareness of our being and implied in it as a teacher implies the pupil, and the taxi-car implies both the driver and the passenger. We discover ourselves as existing with other people and our being as being with others (1996: 60)

According to Mcnomils (1978) this concept of being is what allows us to make sense of ourselves, others as well as things, that is, to care for others, things in a particular way (Mcnomils, 1978: 12). The truth of being is, thus, the understanding of our status as beings or entities whose truth depends on the existence of others, and our acknowledgment of the fact of our world as a with-world. This way of understanding ourselves creates a sense of responsibility for ourselves and the other. It helps us understand that others are not merely means to our ends or actors against our project of authenticity, but as ends in themselves whose realities are indispensable and inescapable to our project of survival. Understanding ourselves in this way, shows that Being is ethically enacted in the world. Heidegger refers to this form of enactment as the care for being.

Heidegger's notion of care for being as an ethical practice means that there is no meaning of being without human being. "The fundamental thought of my thinking is precisely that Being, or the manifestation of Being, needs human beings, and that human beings are only human beings if there are standing in the manifestation of being." The view that human beings are human beings if and only if they stand in the manifestation of being presents the self as a realm of responsibility and commitment to itself and the Other. (Heidegger, 1963) and Satre (1946), for example, writes that "man first of all exists, encounters himself and surges up in the world and defines himself afterward." Heidegger writes that responsibility is not just for the self, but also for the Other. Buber sees "responsibility as the stuff of which the $I$ Thou relation is made" (Vogel, 1970: 159)

In Between Man and Man, Buber (1947) writes that "the saying thou (not I) stands in the origin of all individual human beginning" (Buber, 1947). The authentically realised being is being in relation, specifically, the I-Thou relation. These imports supply the ontological, moral, and epistemic justification for intercultural dialogue, exchanges, and relationships. They also undermine the very pretentions of ethnocentrism that provoke ethnoreligious conflicts. Hence, systematic processes of reorientation such as education, cultural enlightment, and social promotions and policy decisions should be deployed to inoculate the existentialist values of intersubjectivity, tolerance, dialogue, understanding, care and solidarity in our consciousness to build and entrench peace and stability among Nigerian societies. 


\section{CONCLUSION AND RECOMMENDATION}

Ethnoreligious conflicts are pulverising Nigeria's material, cultural, social and human resources. Our study examined why these conflicts thrive in Nigeria, and supplemented existing efforts with an ontological approach. The paper argued that achieving peace in multi-ethnic and religiously diverse societies requires a process of genuine orientation that reworks the human consciousness to accept the inevitability of the Other both to the self and its aspirations for survival.

The paper emphasises the need for government at all levels to pursue a genuine track of national dialogue among ethnicities and religious groups in Nigeria to resolve the country's ethnic and religious conflicts. The paper understands this track as one that attempts to reform the divisive ethnic or local proclivities into nationalist tendencies. To achieve this, the government at the federal level may need a National Dialogue and Reconciliation Committee mandated to liaise with community groups, traditional rulers, interests groups, nongovernment organizations, and religious bodies whose enlightened representatives will decide the terms for dialogue. Nigeria attempted to activate this level of participation through its national conference of 2014 but failed.

The dialogue failed for a good number of reasons. First, the national government that selected the candidates relied its selection criteria on political loyalty. Second, the government assumed that an excellent political reputation represents knowledge of issues affecting people at the grassroots. It failed to acknowledge the possibility of disconnections between its political actors and those they were elected to represent. Third, there was no discussion at the local level through which the voices of the affected people and groups were to be collated. The government assumed that those it unilaterally selected had vast knowledge of their places, people and groups. There was, thus, a lack of involvement of the people whose interests were under consideration.

Unlike previous attempts by the government to activate a platform for national dialogue, this paper's approach recommends that enlightened representatives be empowered to engage directly with their people and the groups they represent at the local or grassroots level to extract grounds for their grievances into actionable points. These actionable points are to be further reviewed by the National Dialogue and Reconciliation Committee into harmonized recommendations for the national government to convert to policy strategies. A genuine commitment to implementing these policy strategies will supplement the existing mechanical and legalistic approaches to conflict management in Nigeria with a policy from the people directed against the ethnic and religious crisis in the country.

\section{BIBLIOGRAPHY}

[1] Adeniyi, M.O. (1993). Religion and Politics: An Eye Bird's View of Development in Nigeria. In R.D. Abubakar (ed.) Religion and Politics in Nigeria. Ilorin: NASR.
[2] Apter, D. (1965). The politics of modernization. Chicago: University of Chicago Press.

Asouzu, I. (2011). "Ibuanyidanda" and the Philosophy of Essence. Calabar: University of Calabar Press.

[3] Ayinla, S.A. (2003). Managing Religious Intolerance and Violence in Nigeria, Problems and Solutions. A Paper Presented at the National Conference on Social Problems, Development and the Challenges of Globalization, Organized by Department of Sociology and Anthropology, Obafemi Awolowo University IleIfe.

[4] Cross, M. (1971). On Conflict, Race Relations, and the Theory of the Plural Society. RACE, XII, (4), 477-494.

[5] Ejizu, C.J. (1993). Religion and Politics in Nigeria: The Perspective of the Indigenous Religions. In R.D. Abubakar, et al. (ed.) Religion and Politics in Nigeria. Illorin: NASR

[6] Fox, J. (1999). Do religious institutions support violence or the status-quo? Studies in Conflict \& Terrorism, 22 (2), 119-139.

[7] Fox. J \& Sandler, S. (2003). Quantifying religion: Toward building more effective ways of measuring religious influence on state-level behaviour. Journal of Church and State, 45 (2), 559588.

[8] Goody J.R. (1961). Religion and Ritual; The Definitional Problem. British Journal of Sociology, (14), 82-91.

[9] Haynes, J. (1994). Religion in third world politics. Colorado: Lynne Rienner Publishers.

[10] Horton RF (1960). A definition of Religion and its Uses. Journal Royal Anthropological Institute, (87) 370-383.

[11] Huntington, S. (1993). The clash of civilizations?. Foreign Affairs, $72(3) 22-49$.

[12] Isiramen, C .O. (2010). Religious crisis and development in Nigeria. In C .O, Isiramen, F.J. Imaekhai and B.O.Igboin (eds), Religion and the Nigerian Nation: Some topical issues. Ibadan: Enjoy Press \& Books.

[13] Kadayifci-Orellana, S. A., (2009). Ethno-Religious Conflicts: Exploring the Role of Religion in Conflict Resolution. In J. Bercovitch, V. Kremenyuk, and I. W. Zartman (eds.), The SAGE Handbook of Conflict Resolution. SAGE: London.

[14] Kimenyi, M., Adibe, J. Djiré, M. Jirgi, A., Kergna, A. Deressa, T. Pugliese, J.E. and Westbury, A. (2014) The Impact of Conflict and Political Instability on Agricultural Investments in Mali and Nigeria. Africa Growth Initiative, (17) p13.

[15] Nasr, V. (1998). Religion and global affairs: Secular states and religious oppositions. SAIS Review, 18 (2), 32-37.

[16] Njoku, E. 2020. Exploring Contemporary Counterterrorism and Perspectives of Terrorism Experts to Combat Boko Haram. (Doctoral Dissertation, Walden University) Walden Dissertations and Doctoral Studies Collection.

[17] Oladipo, O. 2000. Values and National Rebirth. Recall: A Chronicle of Nigerian Events (1), 64-68.

Olatunji, O.A. 2005. Reconciling The Self With The Other: An Existentialist Perspective on The Management of Ethnic Conflicts in Africa. Ibadan: Hope Publishers.

[18] Onah, N., Diara, B.C., \& Uruko, F. 2017. Ethnoreligious Conflicts in Nigeria: Implications on Women. Mediterranean Journal of Social Sciences, 5, (8), 61-61

[19] Onouha, F.C. 2012. "Boko Haram: Nigeria's Extremist Islamic Sect." Aljazeera center for studies. Retrieved via: http://studies.aljazeera.net

[20] Onouha, F.C. 2012. Boko Haram: Nigeria's Extremist Islamic Sect. Aljazeera center for studies. Retrieved via: http://studies.aljazeera.net

[21] Peter, O.F. (1998). Platean Crisis Claimed 54,000 Lives: The Cities of Perpetual Public Work. Accessed via: www.amarujari Retrieved January $20^{\text {th }}, 2020$.

[22] Rostow, W. (1959). The stages of economic growth: A noncommunist manifesto. Cambridge: Cambridge University Press.

[23] Schermerhorn R (1970) Comparative Ethnic Relations. New York: Random House.

[24] Smith, D.E. (1970). Religion and political development. Boston, Massachusetts: Little, Brown. 
[25] Smith, R. T. (1961 "Review of Social and Cultural Pluralism in the Caribbean." American Anthropologist (63)155-157.

[26] Unah J.I. (2000). Difficult Decision Situations: A Phenomenological Ontology of Crisis Management. In A.T. Tymienieke (ed.), Anelecta Husserlianam, LXVIII: 237-246

[27] Vanguard Newspapers Online. Boko Haram: From Islamic Sect to deadly armed group. Accessed via: https://www.vanguardngr.com/2015/06/boko-haram-from-islamicsect-to-deadly-armed-group/ Retrieved January $20^{\text {th }}, 2020$.
[28] Weber M (1968) Economy and Society, ed. Roth G, Wittich C. Berkeley: University of California Press.

[29] Wilson, M. 2018. "Nigeria's Boko Haram attacks in numbers - as lethal as ever." $B B C$ Monitoring. Retrieved through https://www.bbc.com/news/world-africa-42735414. Accessed January $20^{\text {th }}, 2020$. 